\title{
Paulina Cader
}

Velvet Care Sp. z o.o.

e-mail: paulinacader97@gmail.com

\section{Tomasz Lesiów}

Uniwersytet Ekonomiczny we Wrocławiu

e-mail: tomasz.lesiow@ue.wroc.pl

ORCID: 0000-0002-1284-5874

\section{WEGETARIANIZM I JEGO ODMIANY JAKO ALTERNATYWA DLA DIETY TRADYCYJNEJ \\ VEGETARIANISM AND ITS VARIATIONS AS AN ALTERNATIVE TO THE TRADITIONAL DIET}

DOI: $10.15611 /$ nit.2020.36.01

JEL Classification: Q19

Streszczenie: Celem pracy była ocena wiedzy na temat diety wegetariańskiej (wykluczającej z jadłospisu mięso), diety fleksitariańskiej (ograniczającej w jadłospisie mięso) oraz diety tradycyjnej w oparciu o przeprowadzone badania ankietowe. Hipotezą pracy jest wykazanie, że dieta wegetariańska jest wartościowa dla zdrowia człowieka. W badaniu wzięło udział 380 respondentów, bez ograniczeń wiekowych. Stwierdzono, że zdecydowana większość ankietowanych będących na diecie wegetariańskiej cechuje się większą wiedzą na temat spożywanych produktów, jest bardziej zadowolona ze swojej diety oraz pragnie w przyszłości ją kontynuować. Zauważono także duży wzrost zainteresowania respondentów nową formą zdrowego żywienia, jaką jest dieta fleksitariańska. Wzrost poziomu wiedzy na temat sposobów odżywiania i świadomości pozyskiwania żywności powinien skutkować wyeliminowaniem negatywnych opinii wobec diety wegeteriańskiej (weganofobia) oraz przyczynić się do spowolnienia degradacji środowiska, marnotrawstwa żywności i chorób związanych ze spożywaniem zanieczyszczonej i wysoko przetworzonej żywności.

Słowa kluczowe: wegetarianizm, fleksitarianizm, dieta tradycyjna, zdrowe odżywianie.

Abstract: The aim of the study is to evaluate the knowledge about vegetarian diet (which excludes meat from its menu), flexitarian diet (which limits meat in its menu) and traditional diet based on the questionnaire study. The hypothesis of the work is to show that a vegetarian diet is valuable for human health. 380 respondents, with no age limits, took part in the study. It was found that the vast majority of respondents who follow a vegetarian diet are more knowledgeable about the consumed products, are more satisfied with their diet and want to continue it in the future. There was also a large increase in respondents' interest in the new form of healthy eating that is the flexitarian diet. Increased knowledge about nutrition and 
food sourcing awareness should result in the elimination of negative opinions towards a vegan diet (veganophobia) and contribute to slowing down environmental degradation, food waste and illnesses associated with the consumption of contaminated and highly processed food.

Keywords: vegetarianism, flexitarianism, traditional diet, healthy eating.

\section{Wstęp}

W okresie globalizacji związanej z możliwością przemieszczania się zarówno ludzi, jak i towarów wzrasta wiedza społeczeństwa na temat sposobów odżywiania się na innych kontynentach, w poszczególnych państwach. Nie ma również problemu z dopasowaniem produktów żywnościowych do wybranej diety. Dieta w społeczeństwie coraz bardziej wyedukowanym zaczyna nabierać coraz większego znaczenia w dbaniu o zdrowie. Dieta wegetariańska cieszy się niezmiennie wielkim zainteresowaniem $\mathrm{i}$ jest tematem często podejmowanym $\mathrm{w}$ dostępnej literaturze przedmiotu (Frey, 2021; Sun, 2020). Także Cader i Lesiów (2021, w przygotowaniu) scharakteryzowali poszczególne aspekty wegetarianizmu związane z różnymi dziedzinami. Wyjaśniono między innymi istotę wegetarianizmu, historię jego powstania, rodzaje (weganizm, laktowegetarianizm, laktoowopescowegetarianizm, semiwegetarianizm, frutarianizm, polowegetarianizm, fleksitarianizm, owowegetarianizm) oraz omówiono dietę roślinną w kontekście religii, nawyków żywieniowych i względów moralnych. Przedstawiono również tematykę diet w kontekście zdrowia, środowiska, opisano konsekwencje spożywania zbyt dużej ilości mięsa. Przytoczono popularne przykłady zamienników mięsa.

Mniej jest natomiast badań ankietowych na temat stosowania diety wegetarianskiej w społeczeństwie polskim. Śliwińska, Olszówka i Pieszko (2014) sprawdziły stan wiedzy na temat diety wegetariańskiej populacji trójmiejskiej. Według tych autorek osoby na diecie tradycyjnej wiążą wegetarianizm z niższym ryzykiem otyłości (51\%), z mniejszym ryzykiem chorób naczyń krwionośnych, serca (45\%) oraz cukrzycy $(35 \%)$. Natomiast wegetarianie utożsamiają wegetarianizm dodatkowo z niższym ryzykiem występowania nadciśnienia $(80 \%)$, zaparć $(78 \%)$, nowotworów jelita grubego (75\%) oraz niedoborów witamin (54\%).

Śliwińska, Olszówka i Pieszko (2014) wykazały, że 87\% osób będących na tradycyjnej diecie oraz $93 \%$ osób stosujących dietę wegetariańską na pytanie o negatywny wpływ diety wegetariańskiej wykazało szkodliwość stosowania źle zbilansowanej diety wegetariańskiej na zdrowie. Według przekonania tych ankietowanych nieprawidłowo zbilansowana dieta roślinna przyczynia się do problemów z niedożywieniem (71\%), niedorozwojem fizycznym (48\%), jak również z niedokrwistością (54\%). Osoby na diecie wegetariańskiej równie często wiązały źle zbilansowaną dietę wegetariańską z problemem niedoboru witamin $(55 \%)$, niedożywieniem (55\%) oraz z niedokrwistością (58\%). Ponad 95\% respondentów bę- 
dących na diecie wegetariańskiej oraz $63 \%$ osób na diecie tradycyjnej uważało, że dieta wegetariańska jest pełnowartościowa, tj. dostarcza w odpowiednich ilościach wszystkich potrzebnych składników odżywczych. Ponadto według ankietowanych przebywających na diecie wegetariańskiej najważniejszym czynnikiem przyczyniającym się do wegetarianizmu jest w podobnym stopniu dbanie o dobro zwierząt (96\%) oraz troska o własne zdrowie i w takim samym stopniu nielubienie/niepreferowanie smaku mięsa (74\%) i ochrona środowiska (74\%). Dla ankietowanych niebędących wegetarianami najistotniejsze były ochrona środowiska (87\%), moda (61\%), troska o zdrowie (60\%), jak również założenie, że osoby na diecie roślinnej nie lubią smaku mięsa (58\%).

$\mathrm{Z}$ analizy przeprowadzonej przez takich autorów, jak Grzelak, Suliga, Pelczyńska, Sperling i Czyżewska (2017), wynika, że 72\% osób na diecie roślinnej swoje racje pokarmowe uzupełniało suplementami diety. W populacji osób na diecie tradycyjnej stosowanie suplementacji występowało rzadko (ok. 54\%). Najczęściej wybieranymi środkami suplementacyjnymi były preparaty witaminowe, bardziej popularne wśród populacji wegetarian $(76 \%)$ w porównaniu z osobami na diecie tradycyjnej (52\%).

Z wywiadu przeprowadzonego przez Branded w 2019 r. na 17192 osobach wśród społeczności amerykańskiej, które zapytano, czy obecnie stosują dietę wegetariańską lub wegańską, wynika, że stosowały dietę wegetariańską w przeszłości lub planują zmianę diety w przyszłości. Około $10 \%$ respondentów deklaruje dietę wegetariańską lub wegańską, dodatkowe $14 \%$ czasami stosuje dietę rośliną. Natomiast zdecydowana większość, ponad połowa ankietowanych (61\%), nigdy nie stosowała diety wegetariańskiej lub wegańskiej i nie planuje w przyszłości tego zmieniać. Stosowanie diet roślinnych różni się znacznie w zależności od pokolenia. Osoby w wieku 21-38 lat (tzw. millenialsi) zdecydowanie częściej niż starsze pokolenie stosują dietę wegańską lub wegetariańską. Około $15 \%$ tych osób przez cały czas stosuje dietę roślinną, a dodatkowo 16\% czasami stosuje dietę wegetariańską. Millenialsi są bardziej zróżnicowani etnicznie/rasowo, jak również pod względem gustów. Natomiast zdecydowana większość baby boomers (51-69) oraz pokolenia silent generation $(70+)$ dorastała na diecie ziemniaczanej i mięsnej, dlatego nie stosuje diety wegetariańskiej i wegańskiej (Miles, 2019).

W badaniach takich autorów, jak Georgios, Richardson, Nöhre, Brählera, Holzapfel, Hilbert i de Zwaan (2020), przeprowadzonych na 2449 osobach populacji niemieckiej (46,5\% mężczyzn i 53,5\% kobiet, w tym 40,9\% uczestników było w wieku powyżej 55 lat) łącznie 133 osoby $(5,4 \%)$ zgłosiły stosowanie diety wegetariańskiej lub wegańskiej. Podczas gdy większość respondentów zgodziła się, że diety wegetariańskie są zdrowe i nieszkodliwe (56,1\%), tylko 34,8\% uważało, że tak jest w przypadku diet wegańskich. Większość uczestników uważała również, że dieta wegetariańska $(58,7 \%)$ lub wegańska $(74,7 \%)$ może prowadzić do niedoborów żywieniowych. 
Celem pracy była ocena wiedzy na temat diety wegetariańskiej, diety fleksitariańskiej oraz diety tradycyjnej $\mathrm{w}$ oparciu o przeprowadzone badania ankietowe, a ponadto wskazanie, czy w okresie ostatnich kilku lat nastawienie do tej diety uległo jakimś zmianom.

\section{Metodyka badań i charakterystyka grupy badawczej}

Badanie zostało przeprowadzone w okresie od kwietnia do maja $2021 \mathrm{r}$. Wybrano technikę z użyciem kwestionariusza specjalnie skonstruowanego za pośrednictwem formularza strony Google, który z łatwością umożliwia tworzenie ankiet w Internecie. Formularz został zamieszczony na grupach społecznościowych, skupiających zarówno wegetarian, fleksitarian, jak i osoby odżywiające się w tradycyjny sposób.

Po to, aby każda zainteresowana osoba mogła wziąć udział w ankiecie, autorski kwestionariusz obejmował 61 pytań oraz składał się z trzech części. Jedna część była przeznaczona dla osób stosujących dietę wegetariańską, druga - dla osób stosujących dietę fleksitariańską, a trzecia - dla osób stosujących dietę tradycyjną.

Dodatkowo ankieta została podzielona na cztery sektory. Metryczka składała się z pięciu pytań, jedno pytanie przekierowujące do odpowiedniej diety. Z kolei część ogólna zawierała: 16 pytań dotyczących motywów stosowania diety wegetariańskiej, 19 pytań dotyczących motywów stosowania diety fleksitariańskiej, 17 pytań dotyczących motywów stosowania diety tradycyjnej oraz 3 pytania szczegółowe dotyczące wpływu diety wegetariańskiej na zdrowie, dla każdej z trzech podgrup, po zaznaczeniu „tak” w pytaniu: Czy uważa Pan/Pani, że stosowanie diety wegetariańskiej wpływa na zdrowie?", które było wspólne dla wszystkich trzech grup respondentów.

W kwestionariuszu było 41 pytań jednokrotnego wyboru oraz 20 pytań wielokrotnego wyboru. Pytania dotyczyły motywów i stopnia zadowolenia z wyboru diety, liczby spożywanych posiłków, nawyków żywieniowych oraz ogólnej wiedzy na temat wegetarianizmu.

W badaniu wzięło udział 380 przypadkowych respondentów - w tym 264 kobiety $(69,5 \%)$ i 116 mężczyzn $(30,5 \%)$.

Większość badanych mieściła się w przedziale wiekowym 18-25 lat - 154 osoby/40\% (136 kobiet, 18 mężczyzn); 118 osób/31\% to osoby pomiędzy 26 a 35 rokiem życia ( 80 kobiet oraz 38 mężczyzn); 80 osób/21\% to osoby pomiędzy 36 a 60 rokiem życia (34 kobiet oraz 46 mężczyzn). Najmniejszą liczebnością, 14 osób/4\% (8 kobiet i 6 mężczyzn), odznaczały się grupy osób w wieku poniżej 18 lat oraz grupa 6 osób/4\% (6 kobiet i 8 mężczyzn) powyżej 60 roku życia.

Najwięcej respondentów mieszkało w miastach mających powyżej 500 tys. mieszkańców - 132 osoby/35\% (98 kobiet i 34 mężczyzn) oraz na wsi - 94 osoby/25\% (76 kobiet i 18 mężczyzn). Wynika z tego, że co trzecia ankietowana osoba mieszkała w mieście powyżej 500 tys. mieszkańców, w tym prawie co czwarta ko- 
bieta. W mieście do 500 tys. mieszkańców mieszkało 68 ankietowanych/18\% (36 kobiet, 32 mężczyzn). Podobną licznością mieszkańców odznaczały się dwie z sześciu grup: osoby mieszkające w mieście do 50 tys. mieszkańców - 34 osoby/9\% (26 kobiet i 8 mężczyzn) oraz osoby mieszkające w mieście do 100 tys. mieszkańców 32 osoby/8\% (16 kobiet i 16 mężczyzn). Jedynie 20 ankietowanych/5\% mieszkało w mieście do 10 tys. mieszkańców (12 kobiet, 8 mężczyzn).

W badanej grupie najwięcej ankietowanych (37\%) deklarowało wykształcenie wyższe. Podobną liczebnością osób charakteryzowała się grupa ankietowanych deklarujących średnie wykształcenie (32\%). Średnie wykształcenie posiadała co trzecia osoba. Podstawowe wykształcenie miało $17 \%$ osób, natomiast zawodowe $-14 \%$.

$\mathrm{Na}$ podstawie zadeklarowanego przez respondentów dochodu stwierdzono, że dwie z pośród trzech grup liczą tyle samo ankietowanych. Jest to populacja zarabiających poniżej $2600 \mathrm{zz} / \mathrm{os}$. (34\%, 116 kobiet, 14 mężczyzn) oraz zarabiających od 2600 zł/os. Grupa zarabiających do 4000 zł/os. stanowiła 34\% (96 kobiet, 34 mężczyzn). Natomiast podobną liczebnością, ale nieco mniejszą (32\%), charakteryzowały się grupy osób zarabiających powyżej 4000 zł/os., wśród których znajdowały się 52 kobiety i 68 mężczyzn.

Statystyczną analizę danych przeprowadzono testem statystycznym $\chi^{2}$ (Słowińska, 2019). Badano zależność pomiędzy odpowiedziami ankietowanych a kryterium, jakim był rodzaj diety, zakładając poziom istotności $\alpha \leq 0,05$. Otrzymane wyniki po sprawdzeniu jednorodności wariancji za pomocą testu Shapiro-Wilka oraz sprawdzeniu normalności rozkładu przy użyciu testu Lavena poddano obliczeniom programem Microsoft Excel 2016. Przyjęto hipotezę zerową, że pomiędzy odpowiedzią udzieloną na pytanie z ankiety a kryterium „rodzaj diety” nie istnieje zależność.

\section{Wyniki i dyskusja}

W badanej grupie populacji najwięcej ankietowanych, bo aż 190 osób/50\% (138 kobiet i 48 mężczyzn), było wegetarianami (rys. 1). Dietę tradycyjną deklarowały 104 osoby/27,4\%, wśród których znajdowały się 72 kobiety i 32 mężczyzn. Natomiast najmniejsza grupa badanych, licząca 86 osób/22\%, czyli 52 kobiety oraz 34 mężczyzn, zadeklarowała, że jest na diecie fleksitariańskiej. Rozbieżność wyników ma związek prawdopodobnie z tym, że dieta fleksitariańska nie jest jeszcze na tyle popularna i nie każdy o niej słyszał.

Z odpowiedzi respondentów wynika, że najbardziej zadowoleni ze swojej diety są wegetarianie (rys. 2). Spośród 190 badanych wegetarian aż 186/98\% osób na diecie roślinnej potwierdzało zadowolenie ze swojej diety. Podobnym stopniem zadowolenia charakteryzują się fleksitarianie, z 86 badanych 80 osób/93\% deklarowało zadowolenie. Natomiast najmniejszym stopniem zadowolenia charakteryzowały się osoby będące na diecie tradycyjnej - spośród 104 osób zadowolenie ze swojej diety wykazały 72 osoby $/ 69 \%$. 


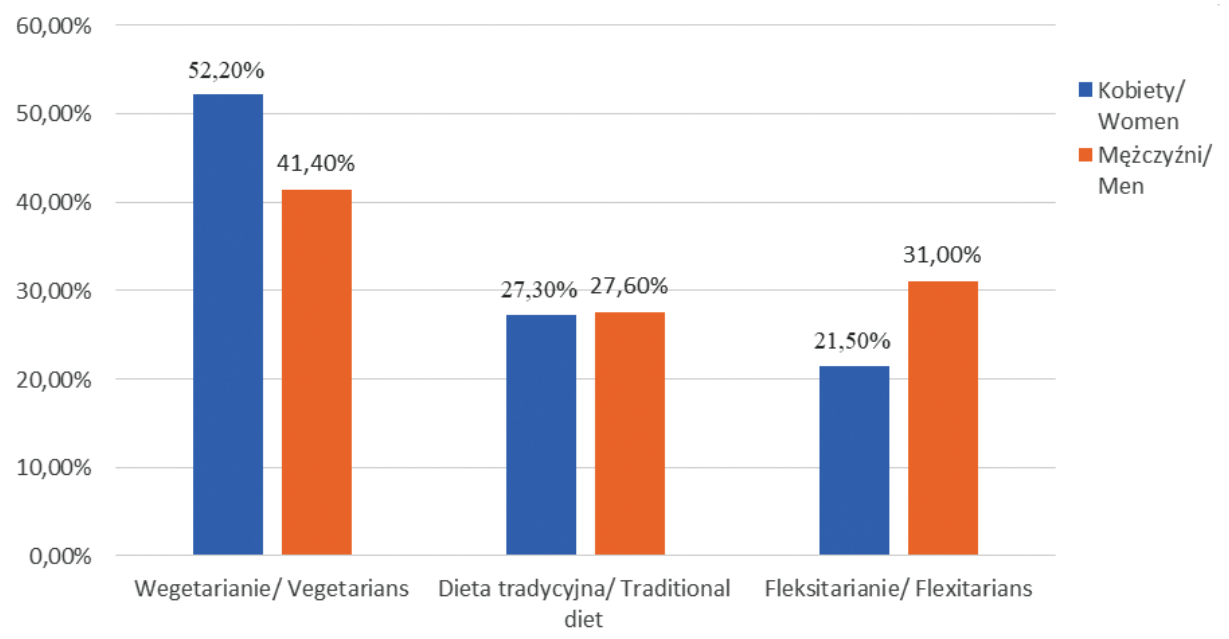

Rys. 1. Dieta stosowana przez ankietowanych/respondentów

Fig. 1. Dietary habits of the respondents

Źródło: opracowanie własne.

Source: own study.

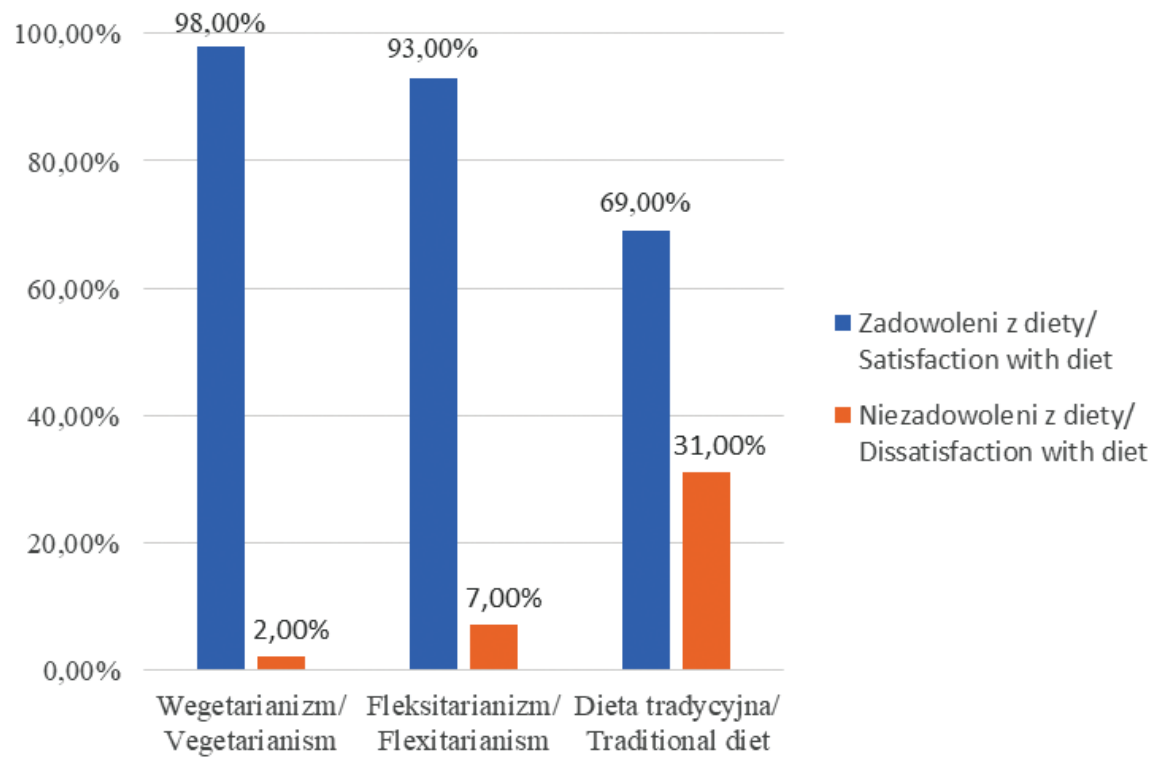

Rys. 2. Poziom zadowolenia respondentów z diety

Fig. 2. Level of satisfaction with the respondents' diet

Źródło: opracowanie własne.

Source: own study. 
Biorąc pod uwagę stopień zadowolenia ankietowanych ze swojej diety, można stwierdzić, że większość wegetarian najczęściej oceniało swoją dietę bardzo dobrze ( 84 osoby/66,7\%) oraz dobrze ( 86 osób/50\%) (rys. 3). Tylko nieliczna grupa badanych oceniła ją przeciętnie (18 osób/25\%) oraz źle (2 osoby/20\%). W przypadku fleksitarian sytuacja wyglądała podobnie, zadowolone w stopniu bardzo dobrym były 32 osoby $/ 25,4 \%$, w stopniu dobrym -44 osoby $/ 25,6 \%$, w przeciętnym - 8 osób/11,1\%, a 2 osoby $/ 20 \%$ oceniły swoją dietę źle. Natomiast w przypadku diety tradycyjnej poziom zadowolenia był nieco mniejszy: bardzo dobrze oceniło swoją dietę 10 osób $/ 7,9 \%$, dobrze - 42 osoby/24,4\%, przeciętnie - 46 osób/63,9\% oraz źle -6 osób/60\%.

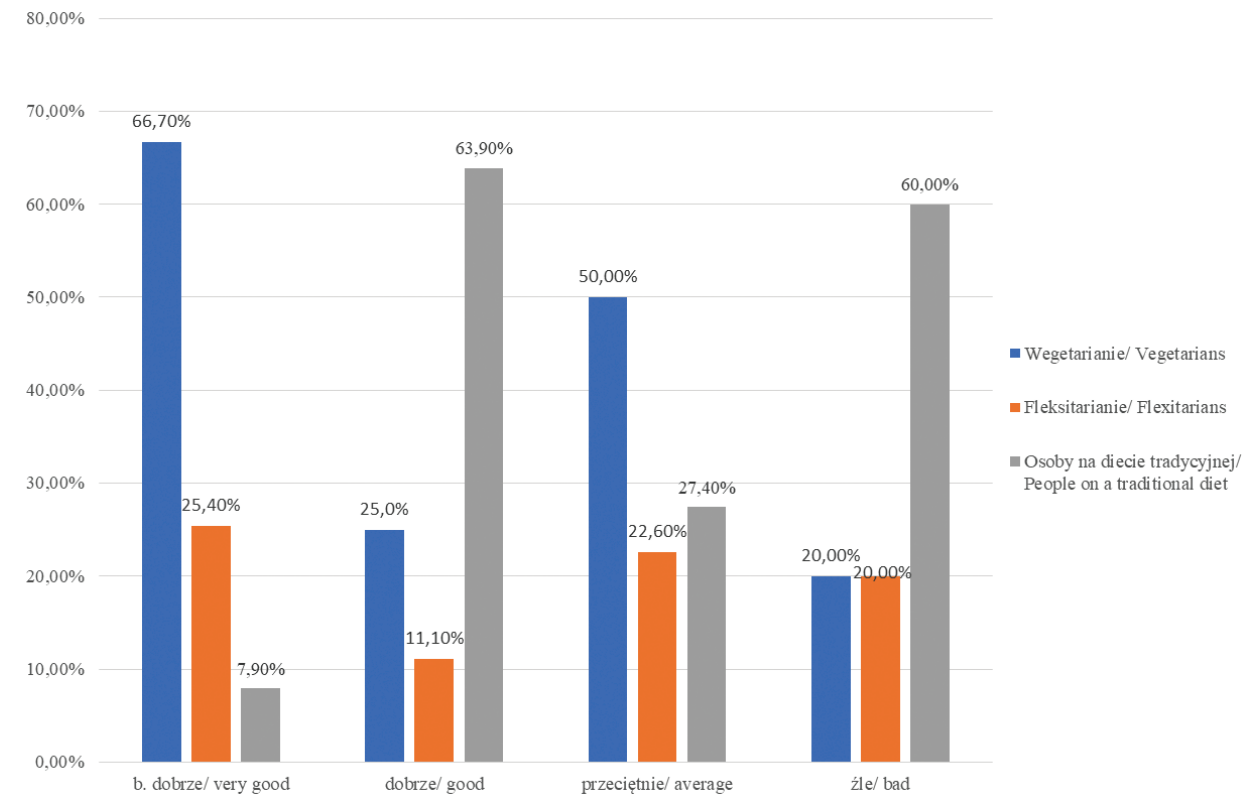

Rys. 3. Stopień zadowolenia respondentów z diety

Fig. 3. The degree of satisfaction with the respondents' diet

Źródło: opracowanie własne.

Source: own study.

Sprawdzono także, czy respondenci posiadają wśród znajomych lub rodziny osobę wykluczającą ze swojej diety mięso. Aż 158 osób/83\% na diecie wegetariańskiej odpowiedziało twierdząco, nieco mniej, bo 64 osoby/74\% deklarujące dietę fleksitariańską, również posiada wśród bliskich osobę na diecie wegetariańskiej. Natomiast w przypadku diety tradycyjnej są to 74 osoby/71\%. Śliwińska, Olszówka i Pieszko (2014) stwierdziły, że w badanej grupie wybranych losowo ankietowanych z Trójmiasta 158 osób/55\% zadeklarowało, że w ich rodzinie lub wśród przyjaciół 
znajdzie się osoba na diecie wegetariańskiej. Są to różne wyniki, które mogą być efektem tego, że w 2014 r. wegetarianizm nie był jeszcze tak popularny.

Przeważająca liczba osób będących na diecie wegetariańskiej (176 osób/56,1\%), tradycyjnej (74 osoby/23,5\%) oraz fleksitariańskiej (64 osoby/20,4\%) zadeklarowała chęć kontynuowania swojej diety (rys. 4). Tylko nieliczni wegetarianie (14 osób/21,2\%) chcą zmienić stosowaną dietę, a także 22 fleksitarian/33,2\% i 30 osób $/ 45,5 \%$ będących na diecie tradycyjnej.

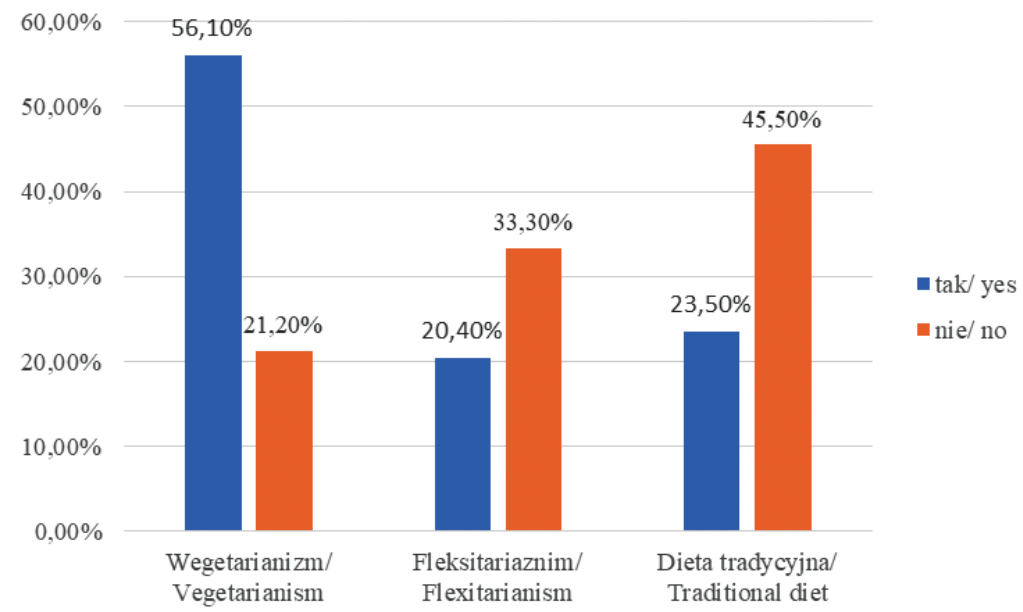

Rys. 4. Deklaracja ankietowanych na temat utrzymania stosowanej diety

Fig. 4. Declaration of respondents on the maintenance of their continued diet

Źródło: opracowanie własne.

Source: own study.

Najwięcej respondentów, bo aż 152 osoby, deklarowało przebywanie na wybranej przez siebie diecie dłużej niż 5 lat, wśród tej grupy były 72 osoby $(47,7 \%)$ na diecie tradycyjnej, 58 osób $(38,1 \%)$ na diecie wegetariańskiej oraz 22 osoby $(14,5 \%)$ na diecie fleksitariańskiej (rys. 5). Najmniej respondentów, czyli 32 osoby, stosuje swoją dietę rok, m.in. 14 wegetarian (43,7\%) i 18 fleksitarian (56,3\%) (rys. 5). Podobne wyniki uzyskały Śliwińska, Olszówka i Pieszko (2014), które stwierdziły, że w badanej grupie 158 osób prawie połowa z nich, bo 71 osoby $/ 45 \%$, stosowała dietę wegetariańską dłużej niż 5 lat.

Biorąc pod uwagę wiedzę na temat spożywanych produktów i potraw oraz świadomość badanych respondentów co do odżywiania, należy stwierdzić, że najwięcej osób (167/44\%) uważało, że poziom wiedzy jest kwestią indywidualną (130/77,8\% wegetarian, 37/22,2\% fleksitarian). Nieco mniej, 141 osób (37\%), stwierdziło, że wegetarianie posiadają większą wiedzę (38 wegetarian/26,9\%, 31 fleksitarian/22\% i 72 osoby na diecie tradycyjnej/51,1\%). Natomiast 72 ankietowanych (19\%) uważa, 


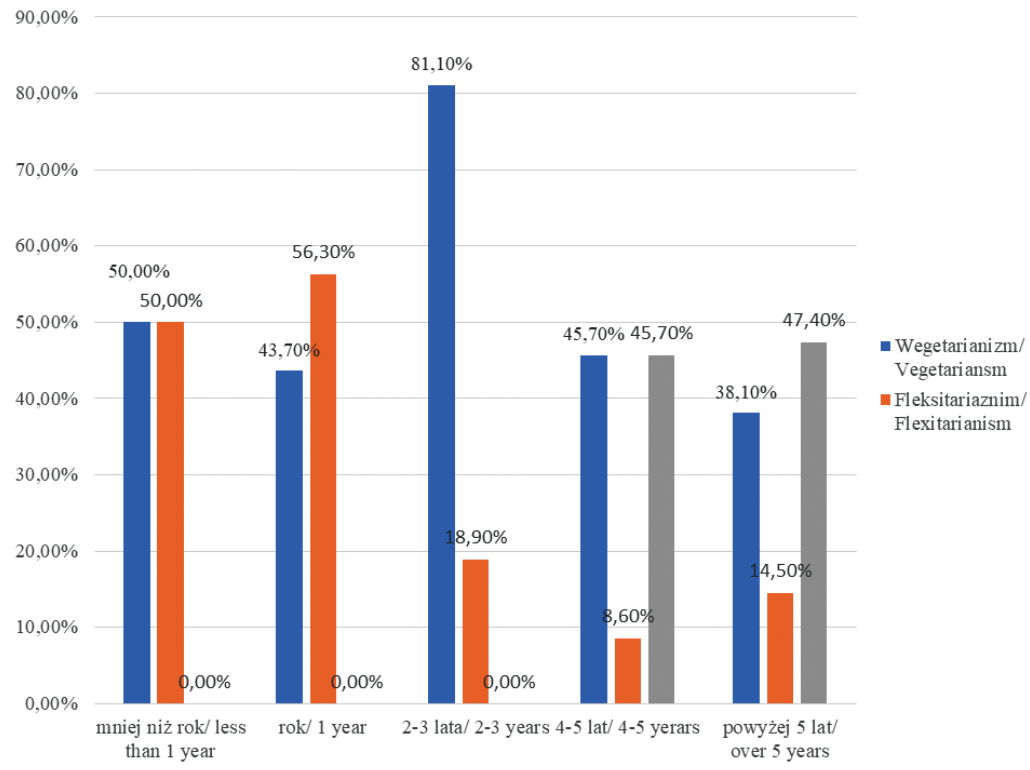

Rys. 5. Okres stosowania diety przez respondentów

Fig. 5. Period of using the diet by respondents

Źródło: opracowanie własne.

Source: own study.

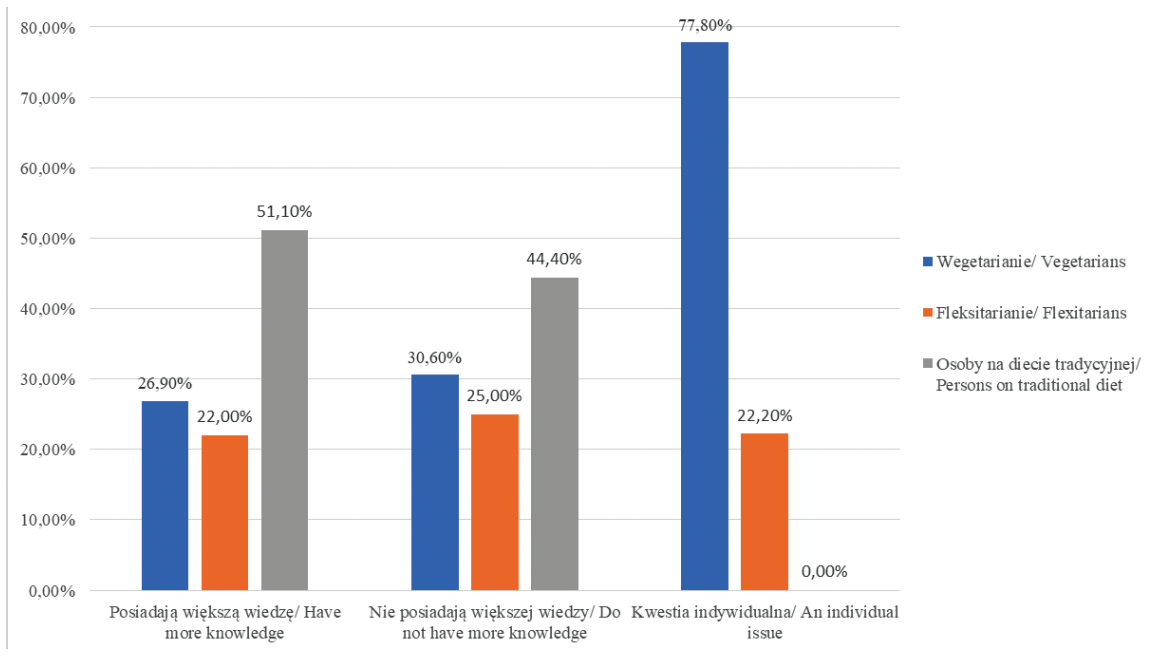

Rys. 6. Wiedza i świadomość respondentów na temat spożywanych produktów i potraw Fig. 6. Knowledge and awareness of respondents about the consumed products and dishes Źródło: opracowanie własne.

Source: own study. 
że wegetarianie nie posiadają większej wiedzy (32 osoby na diecie tradycyjnej/44,4\%, 22 wegetarian $/ 30,6 \%$ i 18 fleksitarian/25\%) (rys. 6). Śliwińska, Olszówka i Pieszko (2014) w swoim opracowaniu oceniły także wiedzę dotyczą wegetarianizmu wśród 82 osób/52\% będących na diecie tradycyjnej i 76 osób/48\% stosujących dietę wegetariańską. Autorki wykazały, że wiedza na temat diety eliminującej mięso wśród wegetarian była wyższa niż wśród osób przebywających na diecie tradycyjnej. Zwrócono również uwagę, że edukacja i świadomość na temat stosowania diety są ważne i powinny być aktualizowane wraz z napływającymi wynikami nowych badań.

Ponad dwie trzecie osób będących na diecie tradycyjnej (72 osoby/63,1\%) twierdziło, że dieta wegetariańska jest droższa, natomiast 32 osoby (20\%) wśród tej grupy uważały, że nie jest (rys. 7). W przypadku wegetarian sytuacja jest odwrotna, 94 osoby $(58,7 \%)$ będące na tej diecie były zdania, że jest ona tańsza, 68 osób $(64,2 \%)$ stwierdziło, że ceny diet są porównywalne, natomiast tylko 28 osób $(24,6 \%)$ uważało, że jest droższa. Osoby będące na diecie fleksitariańskiej miały podobne zdanie co wegetarianie. W badaniach Śliwińskiej, Olszówki i Pieszko (2014) zauważono, że tylko nieliczna część grupy respondentów wiąże stosowanie diety wegetariańskiej z mniejszymi kosztami.

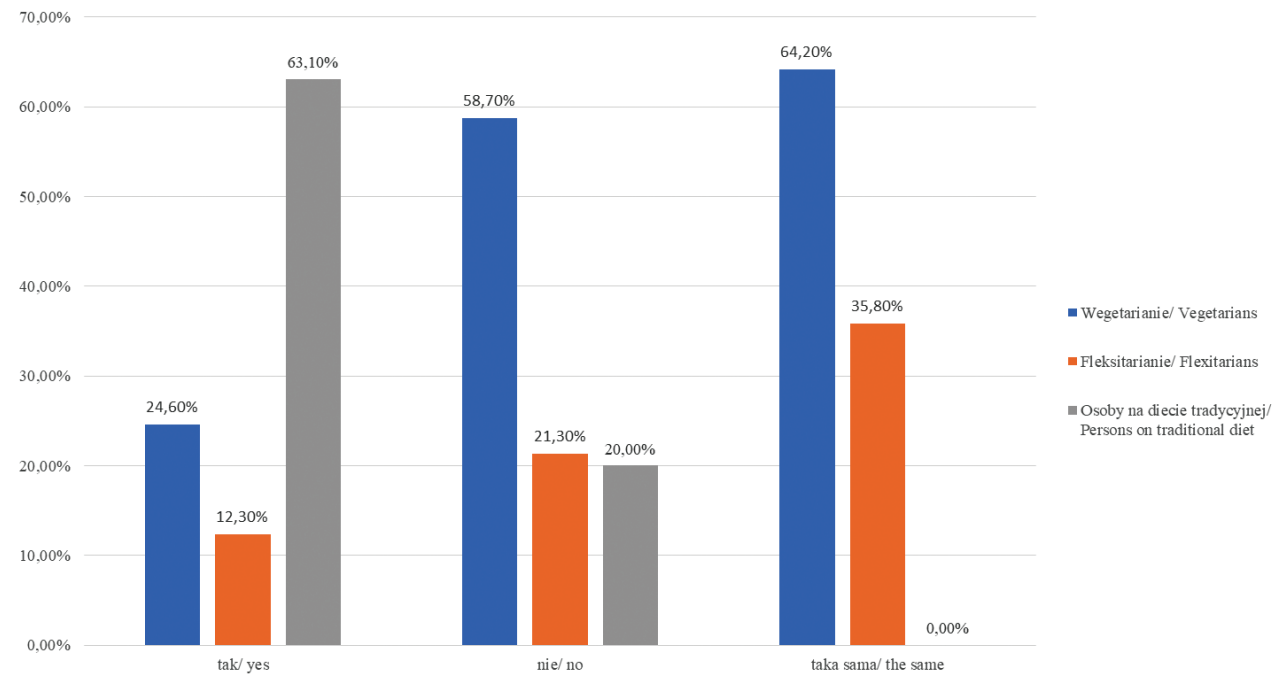

Rys. 7. Ocena kosztów diety przez respondentów

Fig. 7. Assessment of the diet costs by the respondents

Źródło: opracowanie własne.

Source: own study.

Ponad połowa ankietowanych będących na diecie wegetariańskiej (96 osób/60\%) oraz fleksitariańskiej (48 osób/30\%) uważała, że w przypadku diety wegetariańskiej 
konieczna jest suplementacja witaminą $\mathrm{B}_{12}$ oraz witaminą $\mathrm{D}$, w przypadku osób na diecie tradycyjnej podobne zdanie miało jedynie 18 osób/11\%. Na drugim miejscu według liczby odpowiedzi jest opinia, że dieta jest wystarczająca, co potwierdziły 72 osoby $/ 43 \%$ będące na diecie tradycyjnej, 66 osób $/ 40 \%$ będących na diecie wegetariańskiej oraz 30 osób/18\% będących na diecie fleksitariańskiej. Natomiast tylko nieliczni sądzili, że dieta wymaga jedynie suplementacji witaminą $\mathrm{B}_{12}(22$ osoby $/ 91 \%$ na diecie wegetariańskiej, 2 osoby $/ 9 \%$ będące na diecie fleksitariańskiej) oraz witaminą D (14 osób/54\% na diecie tradycyjnej, 6 osób/23\% będące na diecie fleksitariańskiej oraz 6 osób 23\% na diecie wegetariańskiej). Śliwińska, Olszówka i Pieszko (2014) stwierdziły, że 20\% osób będących na diecie wegetariańskiej sądzi, że w przypadku stosowania diety wegetariańskiej konieczna jest suplementacja. Spośród tej grupy ankietowanych $86 \%$ uważało, że potrzebna jest suplementacja witaminą $\mathrm{B}_{12}$ oraz $35 \%$, że witaminą $\mathrm{D}$. Natomiast w przypadku osób będących na diecie tradycyjnej najczęściej wybieraną odpowiedzią było suplementowanie żelaza (52\%), na drugim miejscu był wapń (46\%) oraz witamina $\mathrm{B}_{12}(44 \%)$.

W innej pracy Grzelak, Suliga, Pelczyńska, Sperling i Czyżewska (2017), przeprowadzili badania na grupie 247 osób żywiących się tradycyjnie i grupie 47 osób stosujących dietę wegetariańską. Autorzy ci stwierdzili, że wśród najczęściej preferowanych postaci środków suplementacyjnych występowały preparaty witaminowe, które cieszyły się większą popularnością wśród osób stosujących dietę wegeteriańską (76\%) aniżeli dietę tradycyjną (52\%). W drugiej kolejności pod względem częstości stosowania znalazły się suplementy zawierające składniki mineralne (32 vs. $49 \%$ ), a następnie różne preparaty oparte na ekstraktach roślinnych (18 vs. $21 \%$ ), przy czym w obu przypadkach nie wykazano istotnych różnic pomiędzy badanymi populacjami. Najczęściej przyjmowanym preparatem wśród osób stosujących dietę wegetariańską okazała się kobalamina (wit. $\mathrm{B}_{12}$ ), stosowana przez blisko $62 \%$ ankietowanych z tej grupy wobec pozostałych osób (9\%). Ponadto wegetarianie także istotnie częściej (45\% grupy) w odniesieniu do populacji o diecie tradycyjnej (14\%) deklarowali suplementowanie diety preparatami cholekalcyferolu (wit. $\mathrm{D}_{3}$ ).

Zdaniem 341 respondentów wegetarianizm wpływa na zdrowie (rys. 8). W tej grupie znajduje się 180 wegetarian (95\%), 76 osób (88\%) będących na diecie fleksitariańskiej oraz 85 osób (82\%) będących na diecie tradycyjnej. Natomiast 39 ankietowanych (10\%) uważało, że wegetarianizm nie ma wpływu na zdrowie, między innymi 10 wegetarian (5\%), 10 fleksitarian (12\%) i 19 osób (18\%) będących na diecie tradycyjnej. Z kolei według Śliwińskiej, Olszówki i Pieszko (2014) zdecydowana większość wegetarian (94\%) twierdziła, że stosowana przez nich dieta wpływa na zdrowie, podobne zdanie podzielało $54 \%$ osób będących na diecie tradycyjnej.

Ankietowanym, którzy odpowiedzieli twierdząco na pytanie o to, czy wegetarianizm wpływa na zdrowie, zadano dodatkowo pytanie o wskazanie schorzeń, na które dieta wegetariańska może wpływać w pozytywny sposób. Ponad 3/4 respondentów - 267 osób/78,3\% - uważało, że stosowanie diety wegetariańskiej zmniejsza ryzyko chorób naczyniowych. Nieco mniej ankietowanych wiąże tę dietę z mniej- 


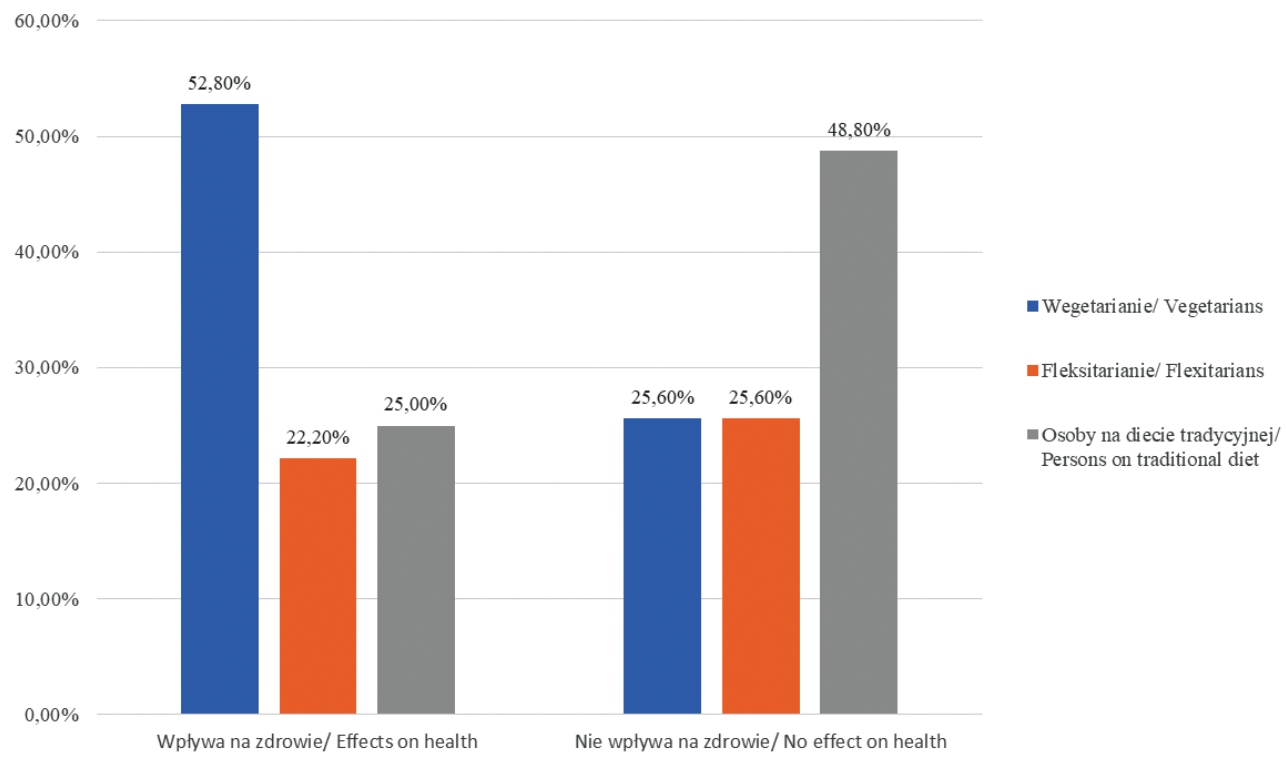

Rys. 8. Wpływ wegetarianizmu na zdrowie według ankietowanych

Fig. 8. The impact of vegetarianism on health according to the respondents

Źródło: opracowanie własne.

Source: own study.

szym ryzykiem nowotworów - 243 osoby $/ 71,4 \%$ oraz z mniejszym ryzykiem nadciśnienia tętniczego - 240 osób/70,2\%. Dodatkowo wegetarianie utożsamiają wegetarianizm z mniejszym ryzykiem występowania otyłości - 215 osób/ $60 \%$, cukrzycy - 217/63,6\%, zespołu metabolicznego - $161 / 47,2 \%$ oraz z niższym poziomem cholesterolu -3 osoby/2\%. Według Śliwińskiej, Olszówki i Pieszko (2014) osoby na diecie tradycyjnej łączyły wegetarianizm z niższym ryzykiem otyłości (51\%), chorób naczyń krwionośnych serca (45\%) oraz z niższym ryzykiem cukrzycy (35\%). Natomiast wegetarianie utożsamiali wegetarianizm dodatkowo z niższym ryzykiem występowania nadciśnienia (80\%), zaparć (78\%), nowotworów jelita grubego $(75 \%)$ oraz niedoborów witamin (54\%). Zauważono podobieństwo wyników w przypadku udzielania odpowiedzi: niższe ryzyko otyłości, niższe ryzyko nadciśnienia tętniczego oraz rzadsze występowanie nowotworów. Natomiast rozbieżne wyniki uzyskano, porównując takie odpowiedzi ankietowanych, jak cukrzyca i choroby naczyń krwionośnych.

Kolejne dodatkowe pytanie zadane ankietowanym dotyczyło sytuacji, kiedy dieta wegetariańska może wpływać na zdrowie. Większość ankietowanych, aż 322 osoby $/ 94 \%$, sądzi, że dieta wegetariańska może mieć negatywny wpływ, jeśli nie jest odpowiednio zbilansowana, natomiast tylko 19 osób/6\% uważało, że nigdy nie ma wpływu na zdrowie. 
Według opinii ankietowanych będących na diecie wegetariańskiej najwięcej osób, bo aż 150/83\%, uważało, że wegetarianizm nie powoduje skutków ubocznych. Tylko nieliczne osoby wskazały na takie zagrożenia zdrowotne, jak np. zwiększone ryzyko niedożywienia oraz niedoboru witamin (po 10 osób/5\%), nieco mniej ankietowanych, tj. 7 osób, uważało, że wegetarianizm zwiększa ryzyko niedokrwistości, a tylko 2 osoby sądziły, że powoduje niedorozwój fizyczny.

W przypadku respondentów będących na diecie fleksitariańskiej 26 osób/34\% uważało, że wegetarianizm nie powoduje skutków ubocznych, podobna liczba ankietowanych stwierdziła, że dieta ta zwiększa niedobór witamin (25 osób/33\%), ryzyko niedokrwistości (23 osoby/30\%) i ryzyko niedożywienia (20 osób/26\%), a zaledwie 6 osób/8\% uważało, że wegetarianizm nie powoduje skutków ubocznych.

Natomiast wśród osób będących na diecie tradycyjnej najwięcej respondentów uważało, że wegetarianizm zwiększa: niedobór witamin (35 osób/41,2\%), ryzyko niedokrwistości (34 osoby/40\%) oraz ryzyko niedożywienia (32 osoby/37,6\%). Według 20 osób/24\% dieta roślinna nie powoduje żadnych skutków ubocznych, a tylko 6 osób/7\% sądziło, że przyczynia się do powstania niedorozwoju fizycznego.

Wyniki zbieżne z wynikami własnymi uzyskały Śliwińska, Olszówka i Pieszko (2014), które stwierdziły, że 87\% osób będących na diecie tradycyjnej oraz 93\% osób stosujących dietę wegetariańską wskazało na szkodliwy wpływ stosowania diety wegetariańskiej na zdrowie. Według przekonania tych ankietowanych nieprawidłowo zbilansowana dieta roślinna przyczynia się do problemów: z niedożywieniem (71\%), niedorozwojem fizycznym (48\%), jak również z niedokrwistością (54\%). Osoby na diecie wegetariańskiej równie często wiązały źle zbilansowaną dietę wegetariańską z problemem niedoboru witamin (55\%), niedożywieniem (55\%) oraz z niedokrwistością (58\%).

Ciekawe też okazały się odpowiedzi respondentów na kilka innych pytań ankiety. Wynika z nich, że najczęściej pojęcie „wegetarianizm” według przedstawicieli każdej z diet kojarzone jest ze sposobem odżywiania - odpowiedzi takiej udzieliły 334 osoby $/ 87,9 \%$. Często wybierany był również styl życia - 186/49\%. Najrzadziej ankietowani natomiast kojarzyli wegetarianizm z rodzajem stowarzyszenia - 10 osób/2,6\% i religią - 8 osób/2,1\%. Z analizy dokonanej przez Śliwińską, Olszówkę i Pieszko (2014) wynika, że wegetarianie równie często utożsamiają pojęcie „wegetarianin” ze stylem życia (zdanie to podzielało aż 112 osób/71\%), jak również ze sposobem odżywiania (odpowiedzi takiej udzieliło 125 osób/79\%). Natomiast ankietowani stosujący dietę tradycyjną najczęściej odpowiadali, że jest ona sposobem odżywiania, odpowiedzi takiej udzieliło aż 144 osoby/91\%, lub wiązali ją ze stylem życia (79 osób/50\%). Tylko nieliczni uważali, że wegetarianizm jest religią, natomiast nikt nie powiązał pojęcia $\mathrm{z}$ rodzajem stowarzyszenia.

W badaniach własnych stwierdzono, że największą popularnością w zakresie pozyskiwania informacji na temat diety według wszystkich przedstawicieli grup (330 osób/86,8\%) cieszy się Internet. Podobną popularnością cieszą się informacje 
pozyskiwane od znajomych i rodziny (188 osoby/49,5\%) oraz z publikacji naukowych (124 osoby/32,6\%). Natomiast najrzadziej w poszukiwaniu informacji na ten temat ankietowani korzystają z konferencji (34 osoby/8,9\%) oraz ze środków masowego przekazu ( 22 osoby $/ 5,8 \%$ ).

Na trudności w pozyskiwaniu składników do swojej diety twierdząco odpowiedziały 74 osoby $/ 39 \%$ będące na diecie tradycyjnej, nieco mniej, bo 64 osoby $/ 34 \%$, na diecie fleksitariańskiej oraz 50 osób/27\% stosujących dietę wegetariańską. Natomiast przeciwne zdanie miały 130 osoby/71\% stosujące dietę wegetariańską, 30 osób/17\% stosujących dietę tradycyjną oraz nieco mniej, 22 osoby/12\% stosujące dietę fleksitariańską.

Większość respondentów (364/95,8\%) robiła zakupy w marketach. Natomiast mniejszą popularnością cieszyły się zakupy na targu - 180 osób/47,4\% i przez Internet -120 osób $/ 31,6 \%$.

Ponad połowa ankietowanych stosujących dietę fleksitariańską (60 osób /61,2\%) i dietę tradycyjną (38 osób/61,2\%) odpowiedziała twierdząco na pytanie, czy myśli o przejściu na dietę wegetariańską. Odmienne zdanie miało 26 osób/28,3\% stosujących dietę fleksitariańską oraz 66 osób/71,7\% stosujących dietę tradycyjną. Podobne wyniki uzyskano przy odpowiedzi respondentów odnośnie do spróbowania diety wegetariańskiej. Ponad połowa ankietowanych -62 osoby $/ 56,4 \%$ stosujące dietę fleksitariańską oraz 48 osób/43,6\% stosujących dietę tradycyjną stwierdziło, że chce spróbować diety wegetariańskiej. Natomiast 24 osoby/30\% stosujące dietę fleksitariańską i 56 osób/70\% stosujących dietę tradycyjną nie zamierza spróbować diety wegetariańskiej.

Najczęstszym czynnikiem decydującym o wyborze diety wegetariańskiej przez ankietowanych było dbanie o dobro zwierząt (180 osób/95\%), a także ochrona środowiska (130 osoby/72\%), jak również troska o własne zdrowie (102 osoby/54\%). Rzadkim powodem było nieakceptowanie smaku mięsa (26 osób/14\%) lub „moda na dietę niemięsną" (6 osób/3\%). W przypadku fleksitarian głównym powodem zmniejszania w swojej diecie mięsa była troska o własne zdrowie (74 osoby/86\%), ochronę środowiska (66 osób/77\%), w mniejszym stopniu dbanie o dobro zwierząt (52 osoby/60\%), a najmniejszą popularnością, podobnie jak w przypadku wegetarian, cechowały się czynniki takie jak nieakceptowanie smaku mięsa (14 osób/16\%), 2 osoby zaznaczyły też modę na dietę niemięsną.

Wyniki zbieżne z wynikami własnymi uzyskały Śliwińska, Olszówka i Pieszko (2014). Według ankietowanych stosujących dietę wegetariańską najważniejszym czynnikiem skłaniającym do wegetarianizmu jest w podobnym stopniu dbanie o dobro zwierząt (96\%) oraz troska o własne zdrowie i w takim samym stopniu nielubienie/niepreferowanie smaku mięsa (74\%) i ochrona środowiska (74\%). Dla ankietowanych niebędących wegetarianami najistotniejsze były ochrona środowiska (87\%), moda (61\%), troska o zdrowie (60\%), jak również założenie, że osoby na diecie wegetariańskiej nie lubią smaku mięsa (58\%). 
W tabeli 1 przedstawiono wyniki testu $\chi 2$, na podstawie których wykazano, że:

1. Nie istnieje zależność między deklaracją kontynuowania swojej diety a rodzajem stosowania diety w przypadku ankietowanych, którzy zaznaczyli odpowiedź twierdzącą. Natomiast w przypadku zaznaczenia odpowiedzi przeczącej istnieje taka zależność.

2. Występuje zależność między czasem stosowania wybranej diety a rodzajem diety. Najkrótszym czasem stosowania wybranej diety charakteryzowały się dieta wegetariańska oraz dieta fleksitariańska. Może to wynikać z tego, że diety te są stosunkowo krótko na rynku i nie są dobrze znane ankietowanym.

3. Nie istnieje zależność między oceną swojej diety a rodzajem diety w przypadku udzielenia odpowiedzi „dobrze” i „źle”, natomiast istnieje zależność w przypadku udzielenia odpowiedzi „,bardzo dobrze” i przeciętnie”. „Bardzo dobrze” najczęściej odpowiadały osoby na diecie wegetariańskiej. Wpływ na taką odpowiedź może mieć fakt, że osoby stosujące dietę wegetariańską zdecydowanie częściej interesują się „zdrowym” odżywianiem, co w konsekwencji prowadzi do dobrego samopoczucia po spożytych posiłkach. Natomiast osoby na diecie tradycyjnej często nie przykładają wagi do potraw, co sprawia, że m.in. spożywają duże ilości przetworzonego pokarmu.

4. Zachodzi zależność między rodzajem diety a odpowiedzią na pytanie, czy wegetarianie posiadają większą wiedzę niż osoby na diecie tradycyjnej. Najwięcej respondentów uważa, że jest to kwestia indywidualna.

5. Istnieje związek między rodzajem stosowanej diety a opinią, czy dieta wegetariańska jest droższa od tradycyjnej diety w przypadku ankietowanych, którzy udzielili odpowiedzi „tak” i „takie same”. Natomiast nie istnieje zależność w przypadku osób, które udzieliły odpowiedzi „nie”; odpowiedzi tej udzieliło najwięcej osób będących na diecie wegetariańskiej.

6. Występuje związek między rodzajem stosowanej diety a opinią, czy dieta wegetariańska ma wpływ na zdrowie w przypadku respondentów udzielających odpowiedzi „nie”, natomiast w przypadku ankietowanych, którzy udzielili odpowiedzi twierdzącej, takiej zależności nie ma.

W przypadku pozostałych pytań ankietowych test $\chi 2$ nie wykazał istotnych statystycznie różnic, można więc przyjąc hipotezę zerową, czyli przedstawić tezę, że przy poziomie istotności $\alpha \leq 0,05$ nie ma zależności pomiędzy odpowiedziami udzielonymi przez respondentów a wybranym kryterium (rodzaj diety).

Zauważono natomiast, że płeć żeńska oraz młodszy wiek były istotnie związane $\mathrm{z}$ dietą wegetariańską. $\mathrm{W}$ odniesieniu do płci jest to całkowicie zgodne $\mathrm{z}$ istniejącą literaturą, z której wynika korelacja między spożywaniem mięsa a pojęciem męskości, ukazując, że mężczyźni identyfikują mięso jako istotny element prawidłowej diety, co w konsekwencji może mieć wpływ na to, że większy odsetek kobiet to wegetarianki. Wywnioskowano również, że wegetarianie byli o wiele młodsi niż osoby spożywające mięso. Stwierdzono, że istnieje odwrotna zależność między wyższym wykształceniem a ilością spożywanego mięsa oraz zamożnością. 
Tabela 1. Wyniki testu $\chi 2$ (różnice istotne statystycznie przy poziomie istotności $\alpha \leq 0,05$ )

Table 1. Results of the $\chi 2$ test (statistically significant differences at the significance level $\alpha \leq 0.05$ )

\begin{tabular}{|c|c|c|c|}
\hline Pytanie/ Question & $\begin{array}{l}\text { Kryterium/ } \\
\text { Criterion }\end{array}$ & $\begin{array}{l}\text { Odpowiedź/ } \\
\text { Answer }\end{array}$ & $\begin{array}{l}\text { Wartość } p / \\
\text { P-value }\end{array}$ \\
\hline \multirow{2}{*}{$\begin{array}{l}\text { Czy zamierza Pan/ Pani w dalszym ciągu } \\
\text { utrzymywać dietę?/ Do you intend to continue } \\
\text { your diet? }\end{array}$} & \multirow{2}{*}{$\begin{array}{l}\text { Rodzaj diety/ } \\
\text { Type of diet }\end{array}$} & Tak/Yes & 0,097322679 \\
\hline & & Nie/ No & $1,53586 \mathrm{E}-05$ \\
\hline \multirow{5}{*}{$\begin{array}{l}\text { Jak długo jest Pan/ Pani na diecie } \\
\text { (wegetariańskiej/ fleksitariańskiej/ } \\
\text { tradycyjnej)? How long have you been on } \\
\text { a (vegetarian/ flexitarian/ traditional) diet? }\end{array}$} & \multirow[t]{5}{*}{$\begin{array}{l}\text { Rodzaj diety/ } \\
\text { Type of diet }\end{array}$} & $\begin{array}{l}\text { Mniej niż rok/ } \\
\text { Less than a year }\end{array}$ & $1,43785 \mathrm{E}-14$ \\
\hline & & Rok/ Year & 1,03569E-05 \\
\hline & & 2-3 lata/ 2-3 years & $2,51021 \mathrm{E}-08$ \\
\hline & & 4-5 lat/ 4-5 years & $4,36027 \mathrm{E}-05$ \\
\hline & & Powyżej 5/ Age 5+ & 2,01741E-07 \\
\hline \multirow[t]{4}{*}{$\begin{array}{l}\text { Jak Pan/ Pani ocenia swoją dietę?/ } \\
\text { How do you evaluate your diet? }\end{array}$} & \multirow[t]{4}{*}{$\begin{array}{l}\text { Rodzaj diety/ } \\
\text { Type of diet }\end{array}$} & $\begin{array}{l}\text { Bardzo dobrze/ } \\
\text { Very good }\end{array}$ & 4,09844E-06 \\
\hline & & Dobrze/ Good & 0,546577523 \\
\hline & & $\begin{array}{l}\text { Przeciętnie/ } \\
\text { On average }\end{array}$ & $3,23288 \mathrm{E}-11$ \\
\hline & & Źle/ Badly & 0,057231891 \\
\hline \multirow{3}{*}{$\begin{array}{l}\text { Czy według Pana/ Pani osoby przebywające } \\
\text { na diecie wegetariańskiej mają większą } \\
\text { wiedzę żywieniową i świadomość dotyczącą } \\
\text { spożywanych przez nie produktów i potraw?/ } \\
\text { In your opinion, do people on a vegetarian } \\
\text { diet have greater nutritional knowledge and } \\
\text { awareness of the products and dishes they } \\
\text { consume? }\end{array}$} & \multirow[t]{3}{*}{$\begin{array}{l}\text { Rodzaj diety/ } \\
\text { Type of diet }\end{array}$} & $\begin{array}{l}\text { Wegetarianie } \\
\text { posiadają } \\
\text { większą wiedzę/ } \\
\text { Vegetarians } \\
\text { are more } \\
\text { knowledgeable }\end{array}$ & $2,88179 \mathrm{E}-10$ \\
\hline & & \begin{tabular}{|l|} 
Wegetarianie \\
nie posiadają \\
większej wiedzy/ \\
Vegetarians do not \\
know much \\
\end{tabular} & 0,001297925 \\
\hline & & $\begin{array}{l}\text { Jest to kwestia } \\
\text { indywidualna/ } \\
\text { It is an individual } \\
\text { matter }\end{array}$ & $2,80883 \mathrm{E}-16$ \\
\hline \multirow{3}{*}{$\begin{array}{l}\text { Czy według Pana/ Pani dieta wegetariańska } \\
\text { jest droższa od tradycyjnej diety?/ } \\
\text { Do you think a vegetarian diet is more } \\
\text { expensive than a traditional diet? }\end{array}$} & \multirow{3}{*}{$\begin{array}{l}\text { Rodzaj diety/ } \\
\text { Type of diet }\end{array}$} & 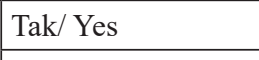 & $1,09286 \mathrm{E}-16$ \\
\hline & & \begin{tabular}{|l}
$\mathrm{Nie} / \mathrm{No}$ \\
\end{tabular} & 0,056161883 \\
\hline & & Takie same/ Same & 1,0041E-09 \\
\hline \multirow{2}{*}{$\begin{array}{l}\text { Czy uważa Pan/ Pani, że stosowanie diety } \\
\text { wegetariańskiej wpływa na zdrowie?/ } \\
\text { Do you think that the use of a vegetarian diet } \\
\text { affects health? }\end{array}$} & \multirow{2}{*}{$\begin{array}{l}\text { Rodzaj diety/ } \\
\text { Type of diet }\end{array}$} & Tak/Yes & 0,524655675 \\
\hline & & Nie/ No & 0,003553828 \\
\hline
\end{tabular}

Źródło: opracowanie własne.

Source: own study. 


\section{Podsumowanie}

Większość ankietowanych będących na diecie wegetariańskiej posiada obszerniejszą wiedzę na temat spożywanych przez siebie produktów, jest bardziej zadowolona ze swojej diety oraz pragnie w przyszłości ją kontynuować. Powodem takiej zależności może być stosunkowo niska jeszcze popularność pozostałych diet w długoletniej tradycji oraz lobbowanie wegetarianizmu jako najlepszej formy diety.

Niewystarczający poziom wiedzy badanych ankietowanych na temat sposobów odżywiania i świadomość pozyskiwania żywności mogą powodować powstawanie stereotypów na temat wegetarianizmu, a to w konsekwencji może prowadzić do wytworzenia się negatywnych opinii wobec osób, które decydują się na wykluczenie ze swojego jadłospisu mięsa (weganofobia). Uświadomienie konsumentów w szerszej populacji pomogłoby zapobiec takim sytuacjom oraz wpłynęłoby na spowolnienie rozwijającej się w bardzo szybkim tempie degradacji środowiska, marnotrawstwa żywności i liczby zachorowań wynikających ze spożywania zanieczyszczonej i wysoko przetworzonej żywności. Istnieje szczególna potrzeba upowszechniania wiedzy wśród młodych konsumentów. Podążanie w kierunku wegetarianizmu oraz fleksitarianizmu może wpłynąc m.in. na poprawę zdrowia i samopoczucia. Przemawia za tym także duży wzrost zainteresowania respondentów nową formą zdrowego żywienia, jaką jest dieta fleksitariańska.

Badając zależności odpowiedzi udzielanych przez respondentów z odpowiedziami udzielanymi w opracowaniu Śliwińskiej, Olszówki i Pieszko (2014), można stwierdzić, że odpowiedzi respondentów na przestrzeni siedmiu lat są do siebie bardzo zbliżone. Niemniej jednak poziom wiedzy z zakresu zdrowego odżywiania, jaki posiadają respondenci, jest nieznacznie wyższy aniżeli ten sprzed siedmiu lat. Jest to zapewne efekt wzrostu wiedzy i świadomości społeczeństwa co do tego, jaki rodzaj składników odżywczych zawierają określone produkty żywnościowe. Nie należy jednak zapominać, że istotnym elementem w promocji zdrowego żywienia oraz stylu życia są kampanie społeczne, których obecnie jest stosunkowo mało. Wiedzę na temat odżywiania ankietowani pozyskują najczęściej z Internetu oraz od rodziny i znajomych, natomiast najrzadziej z konferencji i środków masowego przekazu.

Kładąc nacisk na systematyczne wykonywanie podobnych analiz dotyczących poszczególnych diet, mamy możliwość zorientowania się, jaki jest aktualny trend związany $\mathrm{z}$ wyborem diety przez respondentów oraz w jakim stopniu zmienia się zakres posiadanej przez nich wiedzy $\mathrm{z}$ tej dziedziny.

\section{Literatura}

Cader, P. i Lesiów, T. (2021). Weganizm, wegetarianizm jako diety we współczesnym społeczeństwie konsumpcyjnym. Nauki Inżynierskie i Technologie, 37 (w przygotowaniu).

Frey, M. (2021). Vegetarian diet vs. other diets: Which is best? Pobrane z: https://www.verywellfit.com/ how-does-a-vegetarian-diet-compare-to-other-diets-4770754 
Georgios, P., Richardson, C., Nöhre, M., Brählera, E., Holzapfel, K., Hilbert, A. i de Zwaan, M. (2020). Prevalence and psychopathology of vegetarians and vegans - Results from a representative survey in Germany Scientific Reports, 10, 6840. doi: 10.1038/s41598-020-63910-y

Grzelak, T., Suliga, K., Pelczyńska, M., Sperling, M. i Czyżewska, K. (2017). Ocena częstości stosowania suplementów diety wśród wegetarian oraz osób odżywiających się tradycyjnie. Problemy Higieny i Epidemiologii, 98(2), 170-176.

Miles, K. (2019). Millennials lead the vegetarian movement. Pobrane $\mathrm{z}$ https://gobranded.com/brandedpoll-millennials-lead-vegetarian-movement/

Słowińska, M. (2019). Wykorzystanie testu chi-kwadrat w badaniach preferencji żywieniowych konsumentów. Nauki Inżynierskie i Technologie, 1(32), 24-38.

Sun, W. (2020). Vegetarian diet: Why is it beneficial? (IOP Conf. Series: Earth and Environmental Science 714. 022004). Pobrane z https://iopscience.iop.org/article/10.1088/1755-1315/714/2/022004/pdf

Śliwińska, A., Olszówka, M. i Pieszko, M. (2014). Ocena wiedzy na temat diety wegetariańskiej populacji trójmiejskiej. Zeszyty Naukowe Akademii Morskiej w Gdyni, (86), 133-146. 